\title{
Biginelli Synthesis of Pyrimidones Using Terminal Alkenes as Precursors
}

Gategory

Synthesis of

Heterocycles

Key words

pyrimidones

Biginelli reaction

alkenes

hydroformylation

SYNFACTuth<smiles>[2H][CH+]C=C</smiles>

$\mathrm{Rh}(\mathrm{CO})_{2} \mathrm{acac}(0.25 \mathrm{~mol} \%)$ Xantphos $(2.5 \mathrm{~mol} \%)$ concd $\mathrm{HCl}$ (cat.)

$\overrightarrow{\mathrm{CO} / \mathrm{H}_{2}(1: 1,20 \mathrm{bar}), \mathrm{EtOH}(0.5 \mathrm{M})}$ $100^{\circ} \mathrm{C}, 24 \mathrm{~h}$

$\mathrm{R}=\mathrm{Hex}, \mathrm{t}$-Bu, cyclohexene-4-yl, $\left(\mathrm{CH}_{2}\right)_{4} \mathrm{OH},\left(\mathrm{CH}_{2}\right)_{4} \mathrm{OAc},\left(\mathrm{CH}_{2}\right)_{4} \mathrm{OBn},\left(\mathrm{CH}_{2}\right)_{8} \mathrm{CO}_{2} \mathrm{Me}$, $\left(\mathrm{CH}_{2}\right)_{4} \mathrm{OC}(\mathrm{O}) \mathrm{NHPh},\left(\mathrm{CH}_{2}\right)_{2} \mathrm{CON}(\mathrm{Me}) \mathrm{Ph}, \mathrm{CH}_{2} \mathrm{Phth}, \mathrm{Bn}$<smiles>[R]CCC1NC(=O)NC(C)=C1C(=O)OCC</smiles>

12 examples $52-75 \%$ yield
Significance: Reported is the synthesis of pyrimidinones using a modified Biginelli reaction. In the traditional Biginelli reaction, the use of enolizable aldehydes (i.e., most aliphatic aldehydes) usually leads to low yield of the desired product due to side reactions of the aldehyde. The modification shown above circumvents this issue by ensuring that only a low concentration of aldehyde is present in the reaction at any given time. This is achieved through hydroformylation of a terminal alkene to produce the aldehyde which then undergoes a Biginelli reaction. Interestingly, the catalyst used for the hydroformylation reaction seems to promote the Biginelli reaction as well. Hence, although the term 'tandem reaction' is sometimes misused in the literature, in this case it is entirely accurate.
Comment: Pyrimidines, and by extension pyrimidones, represent a very important class of heterocycles and are essential for all forms of life. Traditional methods for their synthesis usually involve condensation reactions, such as the Biginelli reaction (see Book below). The current work solves an important issue with the Biginelli reaction and allows the use of terminal alkenes as pro-aldehydes, thus avoiding side reactions. The reaction has been optimized with respect to time, temperature, stoichiometry, and pressure. Unfortunately, the optimum pressure for the reaction (necessary for the hydroformylation) is quite high and this may be a hindrance for its widespread adoption. The substrate scope was examined well with respect to the terminal alkene and demonstrated that the reaction conditions were sufficiently mild to tolerate esters, alcohol protecting groups, carbamates, amides, and phthalimides.

Book: S. von Angerer, In Science of Synthesis, Vol. 16; Y. Yamamoto, Ed.; Georg Thieme Verlag: Stuttgart, New York, 2003, 379-572. 